\title{
Forest cover change and carbon stock assessment in Swat valley using remote sensing and geographical information systems
}

\author{
Sajid Ali ${ }^{1}$, Wajid Ali $^{2 *}$, Salman Khan ${ }^{1}$, Abdullah Khan ${ }^{1}$, Zia Ur \\ Rahman $^{1}$ and Arshad Iqbal ${ }^{3}$ \\ 1. Department of Environmental Sciences, University of Haripur-Pakistan \\ 2. National Centre of Excellence in Geology, University of Peshawar-Pakistan \\ 3. Department of Botany, Islamia College, Peshawar-Pakistan \\ *Corresponding author's email: wajeedaali@upesh.edu.pk
}

Citation

Sajid Ali, Wajid Ali, Salman Khan, Abdullah Khan, Zia Ur Rahman and Arshad Iqbal. Forest cover change and carbon stock assessment in Swat valley using remote sensing and geographical information systems. Pure and Applied Biology. Vol. 6, Issue 3, pp850-856. http://dx.doi.org/10.19045/bspab.2017.60089

Received: 20/02/2017

Revised: 30/06/2017

Accepted: 02/07/2017

Online First: 06/07/2017

\section{Abstract}

Swat Valley is located in the Himalayan-Karakorum-Hindu Kush belt in North Western Pakistan. Remote Sensing and GIS techniques were used as a tool to characterize the rate of change, taking into consideration various land use and land cover parameters i.e. forest cover, snow, agriculture, pastures, water bodies, urban and barren land, as indicators of environmental change over the past two decades (1992-2011). The results show that considerable decrease in snow cover, pastures and forest cover has occurred during the period (1992-2011). A comparison of the results of the study with previous work also shows that there is a declining trend in the forest cover and snow, while agricultural and urban areas are expanding. The study also includes an assessment of carbon stock decline derived from the forest cover over the period of study mentioned above.

Keywords: Environmental change; Swat valley; Land use; Land cover; Carbon stocks

\section{Introduction}

Environmental change encompasses any change in biophysical environment, all ecosystems are always under continuous changes that may either be negative or positive changes [1]. Rapid industrialization, urban expansion and deforestation are directly affecting physical, biological and chemical compartments of the environment hence increasing risks to human health through emission of different types of gases into atmosphere [2]. Global environmental change is an important environmental challenge for environmental managers of the $21^{\text {st }}$ century [3]. Environmental scientists already forecast that the same rate of natural resources may result in catastrophic failures [4]. Drivers of environmental change are multi-faceted i.e. direct and indirect, short and long term and natural or anthropogenic. The use of Geographic Information System (GIS)and Remote Sensing (RS) as a tool for 
environmental studies gained high importance amongst scientists, these tools are widely used in watershed management, hydrological studies, drought prediction and mitigation, and forest cover mapping over large areas [5]. GIS and RS plays a very important role in monitoring of land cover and assisting policy makers for appropriate use of land [6]. Land use land cover studies (LULC) provide bird eye view of the change in environment. Such studies serve as a foundation for environmental management and planning, flood and landslides risk assessment and carbon stock assessment among others. Forests play an important role as a sink for carbon emissions. Deforestation may result in the decline of the potential of forests in sequestering carbon from the atmosphere.

The district swat is situated between 3413-55- and 35-53-40 N latitudes and 7047-15 E longitudes in Malakand division of Khyber Pakhtunkhwa. district Swat is located at the base of Hindukush Mountains bounded in North by Chitral, east by Kohistan and Shangla, on the south east by Malakand protected areas and Buner districts, on the west by lower and upper Dir districts. Total area occupied by district Swat is $5337 \mathrm{~km}^{2}$. The district is comprised of three ecological zones i.e. Kalam region is forest zone, MalamJabba is agro forest zone and Barikot is agro scrub forest zone. Swat valley is mostly Colluvial - alluvial piedmont apron. The Piedmont touches its boundary bed. While in its lower plains it has small plains of Piedmont alluvial deposits which are shallow and ranging from 2-8 inches in depth [7]. Soil textures of the district are mainly gravely to stony sandy loam and gravely sandy loam where rocks are mainly igneous and fine grained [8]. There are mainly 7 classes of forest in Swat from tropical deciduous to alpine. Many reports have been published about medicinal plants in Swat according to which Swat district has about 1,550 species of flowering plants and about 55 pteridophytes. Flora of Swat contains about 93 threatened species of plants where $8 \%$ of the plants are threatened and endangered as well, $11.5 \%$ are found vulnerable and $7 \%$ are declared as rare species. After calculation the total percentage of threatened medicinal plants in whole area of Swat reaches approximately 1,550 species which means that $6.3 \%$ of total flora of Swat valley is threatened, $2 \%$ are endangered, $2.7 \%$ are vulnerable and $1 \%$ are rare species [9].

Keeping in view the importance of the ecosystem in the area, this study focuses on the use of GIS and RS tools for the assessment of land use land cover changes in the period of 1992-2011, to pinpoint the causes and to update any existing information regarding the subject. It also aims to estimate the decline in carbon stocks in terms of forest cover in the area.

\section{Materials and methods}

\section{Land use land cover classification}

For this study, LandSAT images of district Swat for two time periods of the same season (27th Sept, 1992 and 20th Oct, 2011) were acquired and classified following supervised classification method. Both images after stacking and mosaicking were subjected to geometric correction. NDSI, NDVI and tasseled cap indices were also run before selection of training sites. ERDAS Imagine 8.4 and ArcGIS 9.3 software were utilized for completion of all the tasks taken in the study. 30 sites were selected for signature generation using seed pixel method and merged to signature to develop one signature per class. Signature alarm utility option was used for signature evaluation before running classification and final maps with seven classes i.e. water bodies, dense forest, open forest, agricultural land, pastures, snow and mix class (Barren soil, settlements and rocks) were generated. For accuracy assessment of classification, 
total numbers of 30 random points were selected through GPS device across the study area. According to accuracy assessment report of the classified maps overall $72 \%$ accuracy has been achieved which is scientifically plausible.

\section{Carbon stock aassessment}

Carbon stocks were assessed using the total forest cover data extracted from the images. The conversion factors and expressions used for calculation are given below [10].

Firstly, the total wood volume in cubic meters $\left(\mathrm{m}^{3}\right)$ was calculated by converting the total forest cover (TFC) by using the equation no $\mathrm{Eq}(1)$

Total wood volume $=$ TFC $\times 1.454 \times 0.396$ (in $\mathrm{m}^{3}$ )

Then the total wood volume from was converted into total dry matter biomass (DMB) using Eq (2)

$\mathrm{DMB}=$ wood volume $\mathrm{x} 0.43$ (in tons)

The dry matter biomass from Eq 2 was converted in to total carbon (TC) by using $\mathrm{Eq}(3)$

$\mathrm{TC}=$ dry matter biomass $\mathrm{x} 0.5$

Finally, the total carbon obtained from Eq. 3 was converted to Carbon Dioxide by using the equation below:

$\mathrm{CO}_{2}$ equivalent $=\mathrm{TC} \times 3.6667$

Calculations were based on total forest cover data, including dense and open forest extracted from Landsat imagery described earlier.

\section{Results and discussion \\ Land use changes}

The results (Figure 1 and Figure 2) highlight that almost every land cover of study area has undergone changes whether positive or negative. Our selected environmental change indicators (dense forest, open forest, pastures, mix class of settlements, barren land and rocks, snow, glaciers and water bodies, agricultural land) show significant increase or decrease during the last nineteen years. Dense forest shows decrease from 178933.5 ha to 108054.4 ha (13.42\% decrease) which amounts to about 3730.47 ha annually over the past nineteen years. Consequently, open forest is increased from 92633.6 ha to 116648.23 ha. Agricultural land shows an increase during study years i.e. in 1992 only $9.06 \%$ area of Swat was under cultivation but according to 2011 classified image results agriculture is almost occupying $23.65 \%$ area of Swat in 2011. Pastures also show decrease from $15.92 \%$ to $5.16 \%$ of the total area during the nineteenyear period of the study, while settlements, barren soil, agricultural land and rocks show considerable increase.

A recent study, puts the gross annual deforestation at 1268 ha over a period of eight years (2001-2008) in specific parts of the valley [11]. A 2009 study also highlighted the high rate of deforestation in Swat valley and attributed it to the conversion of land for agricultural purposes. This study suggested that no empirical link of deforestation to poverty could be established [12]. Pellegrini attributed the high rate of deforestation in Swat valley to institutional failures [13]. However, it is safe to assume that the cumulative impact of these factors in combination with other social and economic factors like the lack of alternate means of energy for domestic purposes, lack of jobs, poverty, and increase in population and over grazing may as well contribute to the worsening situation.

The dynamics of land cover and land use change are different in different areas of Swat valley, depending upon the socioeconomic and ecological conditions of the area and due to the diversity in local institutional settings. In the most fertile area at the bottom of the valley land conversion for agriculture has historically been the main cause of deforestation, while pastures face threats due to overgrazing. Detail ecological, phytosociological and ethnobotanical studies conducted in various parts of the district has also stressed the need for a proper ecological 
management and conservation [14-18]. A study on land use land cover change dynamics in the valley for the period 19692007 spanning over forty years also reported significant decline in forest resources in Kalam, Malam Jabba and Barikot regions. Annual percent decrease in forest cover calculated in the study for Kalam, Malam Jabba and Barikot regions were $1.86 \%$, $1.28 \%$ and $0.80 \%$ respectively. They also attributed this decline in forest cover to agricultural expansion citing overgrazing of pastures and institutional failures as drivers of land use change among others [19-21]. Similarly, a study conducted in the Kumrat valley, which lies in the Upper Dir district and borders the study area on the western margin reported a $100 \%$ increase in agricultural land [22]. One reason behind this increase in agriculture is the fastgrowing rate of population in the study area. The population estimates for Swat district for the year 2010 show an increase of 535288 persons since 1998. The growing livelihood requirements of population and weakness of institutions is resulting in conversion of pastures and forests land into agricultural areas and settlements

The decrease in snow cover could be attributed to low snowfall or increase melting in the season. A detail analysis is needed to ascertain the true picture of snow cover changes in the valley by integrating meteorological records and remote sensing data.

Carbon stock is the amount of carbon present in a reservoir that may accumulate or release carbon. Figure 3 summarizes and compares the results of carbon stocks for the year 1992 and 2011. The total percent decline in carbon stocks as a result of deforestation during the period of the study was recorded to be 17.25 percent.

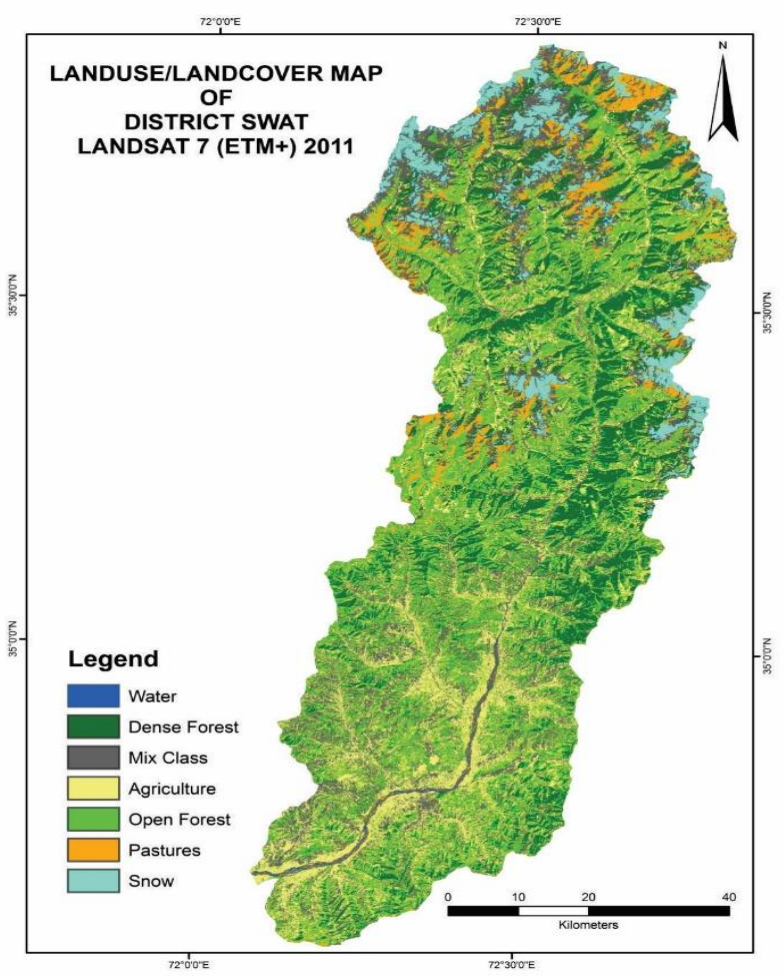

Figure 1. Visual comparison of the processed satellite imagery for the year 1992 and 2011 


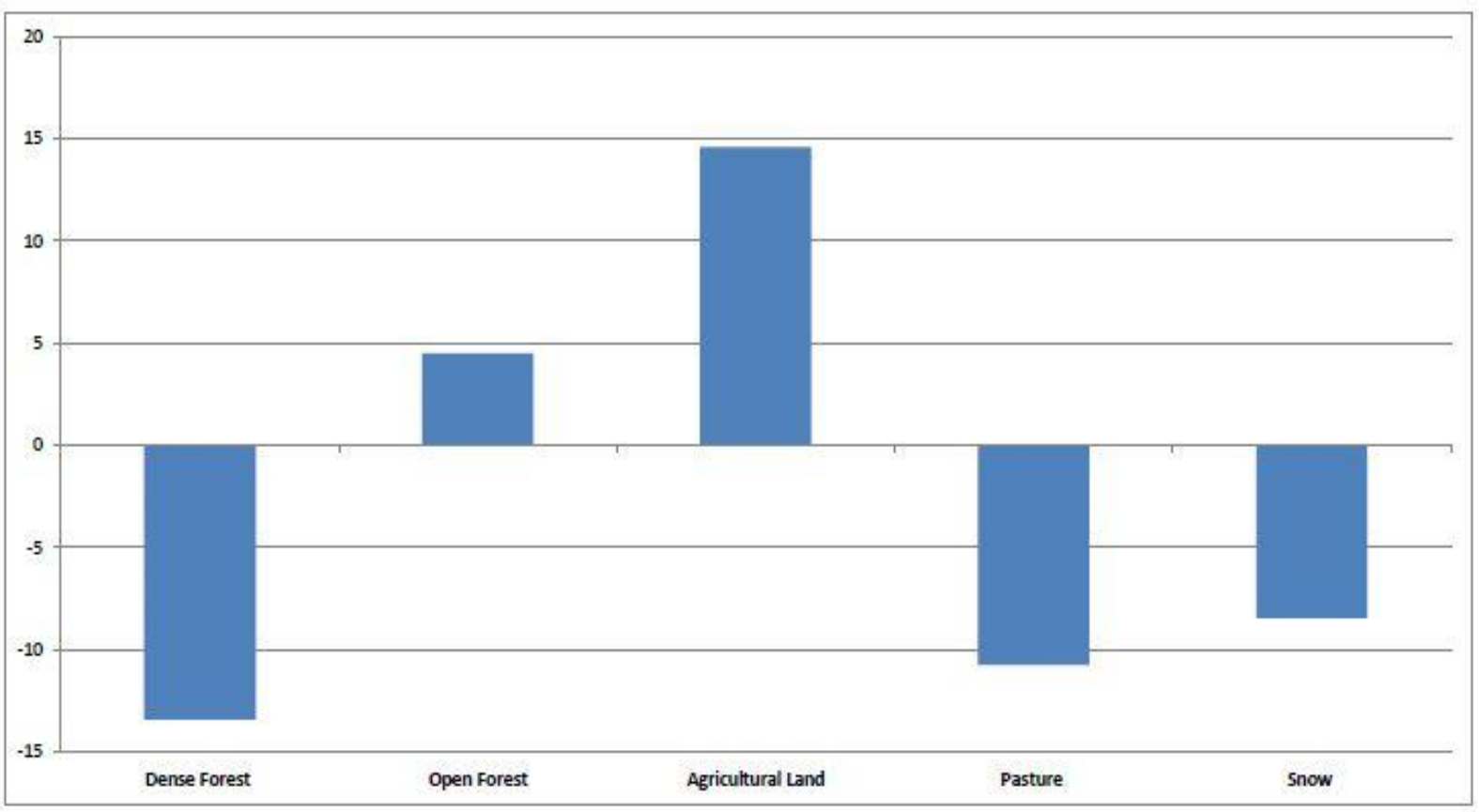

Figure 2. Showing the percent decrease and increase for different land use land cover components in the study area for the duration 1992-2011

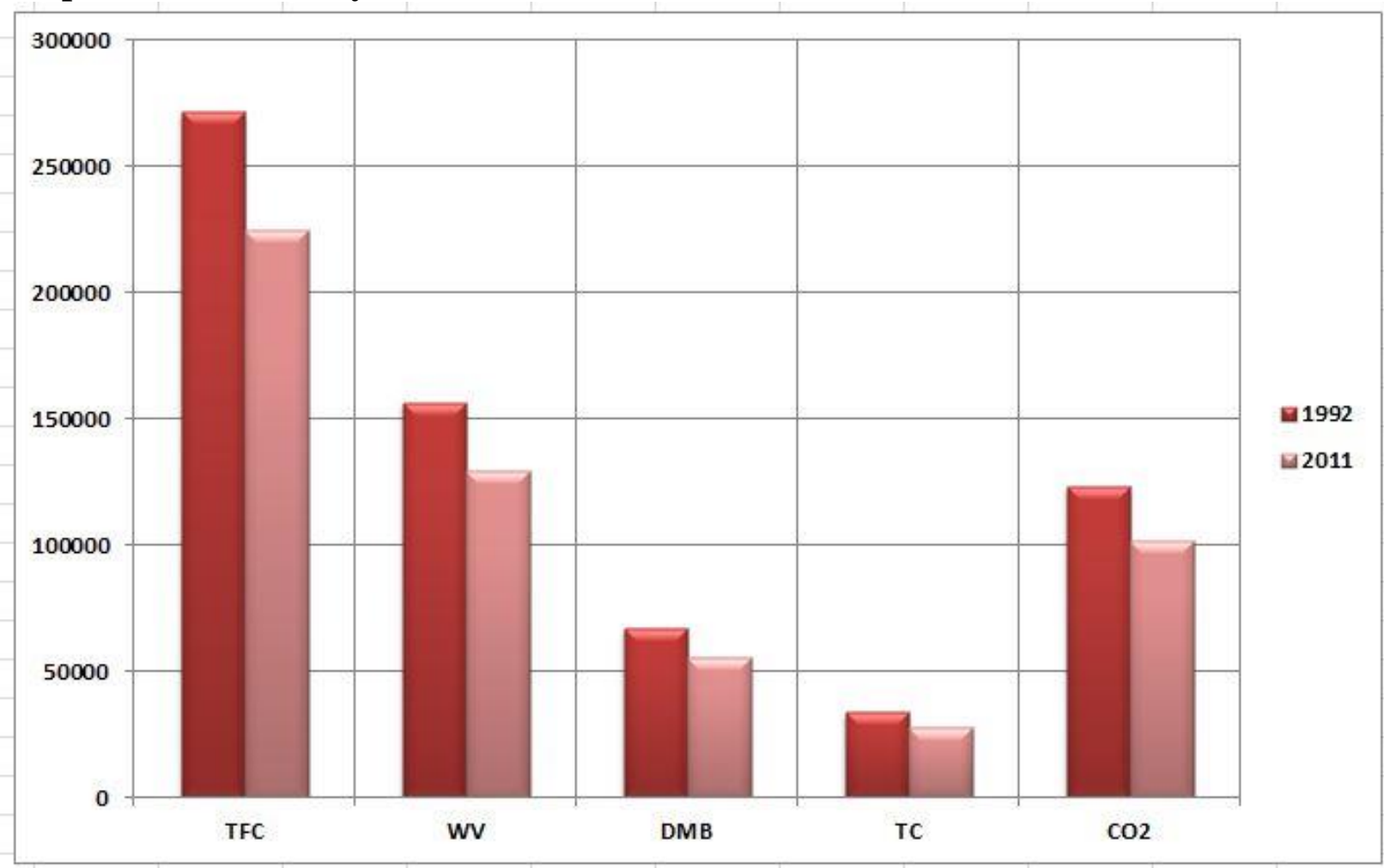

Figure 3. Decline of total forest cover, Wood volume, Dry mass biomass, Total carbon and equivalent carbon dioxide during the period of study (1992-2011) 


\section{Conclusions}

Considerable decline in the forest cover over the past few decades has been reported in this study. Forest cover has decreased by $13.42 \%$ at an annual rate of 3730 ha. Pastures also show a decrease from $15.92 \%$ to $5.16 \%$ of the total area during the nineteen-year period of the study. A considerable increase in agriculture land was recorded during the study period. The agriculture land increased from $9.06 \%$ of the total area in 1992 to $23.65 \%$ in 2011. The comparison of estimates of the Carbon stocks between 1992 and 2011 show a decline of 17.25 percent. Deforestation due to agriculture expansion and institutional failures is resulting in the decline of precious forest resources in the valley. Detail ground surveys to assess the carbon stocks in the valley are recommended for further research. A detail analysis is needed to ascertain the true picture of snow cover changes in the valley by integrating meteorological records and remote sensing data.

\section{Authors' contributions}

Conceived and designed the experiments: $\mathrm{S}$ Ali \& W Ali, Performed the Experiments: S Ali \& W Ali, Analyzed the Data: S Ali, W Ali, S Khan \& A Khan, Contributed reagents/ materials/ analysis tools: S Khan, A Khan \& A Iqbal, Wrote the paper: S Ali \& W Ali.

\section{References}

1. Jeremy BC, Jackson, Michael X, Kirby, Wolfgang $\mathrm{HB}$, Karen AB, Louis WB, Bruce JB, Roger HB, Richard C, Jon E, James AE, Terence PH, Susan K, Carina BL, Hunter S L, John MP, Charles HP, Robert SS, Mia JT \& Robert RW (2001). Ecological. Historical Overfishing and the Recent Collapse of Coastal Ecosystems. Science 80 (293): 629-637.

2. Serageldin MA (2006). Ecological and environmental change. In:Sirageldin I, editor. Sustainable Human Development,
Encyclopedia of Life Support Systems. (EOLSS), Oxford: EOLSS Publishers.

3. Crutzen P \& Stoermer E (2000). The Anthropocene. Global Change Newsletter 47: 17-18.

4. Steffen W (2004). Global Change and the Earth System: A Planet Under Pressure. IGBP Secretariat, Sweden.

5. Melesse A, Weng Q, Prasad S \& Senay G (2007). Remote Sensing Sensors and applications in environmental resources mapping and modelling. Sensors 7(12): 3209-3241.

6. Lunetta RS, Knight JF, Ediriwickrema J, Lyon JG \& Worthy LD (2006). Landcover change detection using multitemporal MODIS NDVI data. Remote Sens. Environ 105(2): 142-154.

7. Khan MA, Anwar M \& Baig S (1991). Mountain Environmental Management in Swat District, Pakistan. ICIMOD, Nepal pp: 15-21.

8. Nawaz S (1987). Socio-economic evaluation of Swat river watershed project, Forest Education Division, PFI, Pakistan.

9. Shinwari Z (2000). Ethno Botany and its application to Conservation in SwatHimalaya, Pakistan. WWF-Pakistan.

10. Von Mirbach, M. (2000). Carbon budget accounting at the forest management unit level: an overview of issues and methods. Canada's Model Forest Program, Can. For. Serv., Nat. Resour. Can., Ottawa, ON, http://dsp-psd. pwgsc. gc. ca/Collection/Fo42-312-2000E. pdf. Accessed on Feb, 15, 2006.

11. Qamar FM, Abbas S, Saleem R., Shehzad K \& Iqbal A (2012). Forest cover change assessment in conflictaffected areas of northwest Pakistan: The case of Swat and Shangla districts. $J$ Mt Sci 9(3): 297-306.

12. Khan SR \& Khan SR (2009). Assessing poverty-deforestation links: Evidence 
from Swat, Pakistan. Ecol Econ 68(10): 2607-2618.

13. Pellegrini L (2011). The Rule of the Jungle in Pakistan: A Case Study on Corruption and Forest Management in Swat Swat. In: Corruption, Development and the Environment pp.121-147

14. Ilyas M (2013). Some ethnoecological aspects of the plants of qalagai hills, kabal valley, swat, Pakistan. Int J Agric Biol 15(5): 801-810.

15. Ilyas M, Qureshi R, Akhtar N, Munir M \& Haq ZA (2015). Vegetation analysis of Kabal valley, district Swat, Pakistan using multivariate approach. Pakistan $\mathrm{J}$ Bot 47: 77-86.

16. Hussain F, Iqbal I \& Durrani MJ (2006). Ethnobotany of Ghalegay, District Swat, Pakistan. Acta Bot Yunnanica 28(3): 305-314.

17. Ilyas M, Shinwari ZK \& Qureshi R (2012). Vegetation composition and threats to the montane temperate forest ecosystem of qalagai hills, swat, khyber pakhtunkhwa, Pakistan. Pakistan J Bot 44: 113-122.

18. Hussain F, Ilyas M \& Kil BS (1995). Vegetation Studies of Gribanr Hills, District Swat, Pakistan. Korean $J$ Ecooogy 18: 207-218.

19. Qasim M, Hubacek K, Termansen M \& Fleskens L (2013). Modelling land use change across elevation gradients in district Swat, Pakistan. Reg Environ Chang 13(3): 567-581.

20. Qasim M, Hubacek K, Termansen M \& Khan A (2011). Spatial and temporal dynamics of land use pattern in District Swat, Hindu Kush Himalayan region of Pakistan. Appl Geogr 31(2): 820-828.

21. Qasim M, Hubacek K \& Termansen M (2013). Underlying and proximate driving causes of land use change in district Swat, Pakistan. Land use policy 34: 146-157 (2013).

22. Ahmad A \& Nizami SM (2015). Carbon stocks of different land uses in the Kumrat valley, Hindu Kush Region of Pakistan. J For Res 26(1): 57-64. 